\title{
ANALISIS FAKTOR-FAKTOR YANG MEMPENGARUHI KECENDERUNGAN KECURANGAN (FRAUD) DI DINAS KESEHATAN KOTA PONTIANAK BERDASARKAN TEORI FRAUD TRIANGLE
}

\section{ANALYSIS OF FACTORS AFFECTING TRIANGLE FRAUD TRENDS IN HEALTH DEPARTMENT OF PONTIANAK CITY BASED ON THE TRIANGLE FRAUD THEORY}

\author{
Elia Calsia \\ Fakultas Ekonomi dan Bisnis Universitas Trisakti \\ e.calsia@yahoo.com
}

\begin{abstract}
Abstrak
Penelitian ini bertujuan untuk mengetahui pengaruh variabel kepuasan kompensasi, gaya kepemimpinan, keefektifan sistem pengendalian internal, kultur organisasi, dan perilaku tidak etis terhadap kecenderungan kecurangan (fraud) di Dinas Kesehatan Kota Pontianak. Populasi penelitian ini adalah seluruh pegawai tetap/Pegawai Negeri Sipil (PNS) yang bekerja di Dinas Kesehatan Kota Pontianak dan sampel yang diambil sebanyak 85 Pegawai Negeri Sipil (PNS). Metode penelitian menggunakan metode penelitian kuantitatif dengan data primer yang diperoleh dari data kuisioner yang diukur dengan menggunakan skala Likert. Teknik analisis data yang digunakan adalah teknik analisis regresi linier berganda dengan program SPSS 22.00 for windows. Hasil penelitian menunjukkan bahwa variabel kepuasan kompensasi, keefektian sistem pengendalian internal, kultur organisasi, dan perilaku tidak etis secara signifikan berpengaruh terhadap kecenderungan kecurangan (fraud) di Dinas Kesehatan Kota Pontianak, sedangkan variabel gaya kepemimpinan tidak berpengaruh terhadap kecenderungan kecurangan (fraud) di Dinas Kesehatan Kota Pontianak.
\end{abstract}

Kata Kunci : Fraud, Pemerintahan, Manajemen

\begin{abstract}
This study aimed to finding out the effect of variable appropriate compensation, leadership, internal control effectiveness, organizational culture, and unethical behavior on the fraud trend of Department of Health in Pontianak City. The population of this research were all Civil Servants who worked on the Department of Health in Pontianak City and the used sample were 85 Civil Servants. The used method was quantitative method with primary data which obtained from questionnaire measured by using Likert scale. The used data analysis technique was multiple linear regression analysis with SPSS 22.00 for windows program. The result of this research indicated that the variable of appropriate compensation, internal control effectiveness, organizational culture, and unethical behavior significantly influence on fraud in Department of Health in Pontianak City, meanwhile variable of leadership had no significant effect on fraud in Department of Health in Pontianak City.
\end{abstract}

Keywords : Fraud, government, management

\section{PENDAHULUAN}

Kecurangan akuntansi menjadi hal yang masih sering terjadi di Indonesia seperti pencatatan yang dimanipulasi, penghilangan dokumen, dan mark-up yang merugikan keuangan dan perekonomian negara Umumnya kecurangan akuntansi erat kaitannya dengan korupsi. Kata korupsi menurut UU Nomor 31 Tahun 1999 adalah setiap orang yang dengan sengaja melawan hukum untuk melakukan perbuatan dengan tujuan memperkaya diri sendiri atau orang lain atau suatu korporasi yang mengakibatkan kerugian keuangan negara atau perekonomian negara.

Di Indonesia, tindak korupsi sudah menjadi suatu hal yang umum dan menjadi persoalan yang berkepanjangan, hal ini dibuktikan dengan Negara Indonesia yang memiliki peringkat yang tinggi di antara negara-negara lain. Menurut Transparency Internal Indonesia (TII), indeks persepsi 
korupsi di Indonesia pada tahun 2016 berada di angka 37 dari rentang 0 sampai dengan 100, semakin tinggi skor semakin rendah tingkat risiko korupsi. Dengan skor tersebut, Indonesia berada pada posisi ke-90 dari 176 negara.

Sepanjang 2001-2017, Mahkamah Agung menetapkan kerugian negara terbesar berasal dari sektor keuangan yang nilainya mencapai Rp 34,9 triliun dengan 109 kasus dan 192 terdakwa. Nilai tersebut hampir sepuluh kali lipat dari sektor pemerintahan atau 120 kali lipat dari sektor hukum dan politik. (Beritagar: Kamis, 27 Juli 2017). Data Indonesian Corruption Watch (ICW) yang dirilis pada bulan Februari 2017, mencatat terdapat 482 kasus korupsi di Indonesia selama tahun 2016, dengan total 1.101 tersangka dan kerugian negara yang mencapai Rp 1,45 triliun (Kompas.com: Selasa, 12 September 2017).

Instansi pemerintah mempunyai peranan penting dalam pelaksanaan sistem pemerintahan agar dapat tercapainya tujuan sehingga harus didukung dengan perilaku atau tindakan baik dari pegawainya. Namun, pada kenyataannya kasus korupsi justru terjadi di sektor pemerintahan pusat maupun pemerintahan daerah. Menurut ICW, pada tahun 2016, terdapat 219 kasus yang terjaid di Pemerintah Kabupaten dengan total nilai kerugian negara sebesar Rp 478 miliar, diikuti Pemerintah Kota sebanyak 73 kasus dengan niolai kerugian negara mencapai Rp 247 miliar. (merdeka.com: Minggu, 19 Februari 2017).

Indeks Prestasi Korupsi Indonesia dibidang pemberantasan korupsi masih sangat rendah, yakni sekitar 2,8 dari range satu sampai dengan sepuluh. Adapun pelaku korupsi berasal dari aparat pemerintah yang bekerja di lembaga pemerintahan yakni lembaga eksekutif, lembaga legsilatif, dan lembaga-lembaga pemerintahan lainnya. Penasehat KPK, Abdullah Hehamahua mengungkapkan dari 3,7 juta sampai 4 juta jumlah pegawai negeri sipil, terdapat 60 persen diantaranya merupakan pelaku korupsi. Pemicu tindak korupsi terjadi dikalangan PNS dikarenakan rendahnya gaji yang diterima sehingga tidak cukup untuk memenuhi kebutuhan sehari-hari, rendahnya sikap mental dari masing-masing pribadi pegawai pemerintah, serta timbulnya celah atau kesempatan didalam wewenang pekerjaannya. Selain itu, faktor keserakahan, kerakusan, serta rasa tidak puas menjadi pemicu terjadinya tindak korupsi pegawai negeri sipil dengan jabatan yang tinggi.

Korupsi sudah menyebar di berbagai aspek termasuk aspek pelayanan publik dalam bidang kesehatan, seperti adanya kebijakan-kebijakan pemerintah yang tidak tersalurkan dengan baik. ICW mengungkapkan terdapat kerugian sebesar Rp 605 miliar yang berasal dari objek korupsi di bidang korupsi yakni dana alat kesehatan sebesar Rp 543,1 miliar dan dana jaminan kesehatan sebesar Rp 62,1 miliar. Korupsi kesehatan yang ditemukan tekait dengan markup atau penggelembungan harga pengadaan barang dan jasa, disusul dengan penyalahgunaan anggaran dan penggelapan yang menjadi modus korupsi terbanyak kedua.

ICW kembali merilis temuan terkait korupsi yang terjadi di bidang kesehatan di Indonesia, dimana Kalimantan Barat menempati urutan ke 16 dengan jumlah 5 kasus dan kerugian mecapai Rp 92,7 miliar. Penyalahgunaan alat kesehatan, dana jaminan kesehatan, infrastruktur rumah sakit, dan dana obat-obatan menjadi empat penyebab utama tindak korupsi. (Tribun Pontianak: Senin, 11 September 2017).

Teori Fraud Triangle yang dikembangkan oleh Donald R. Cressey (1953) menjelaskan tiga faktor yang melatarbelakangi terjadinya suatu tindak kecurangan yaitu tekanan (pressure), kesempatan (opportunity), dan rasionalisasi (rationalization). Sehubungan dengan variabel yang digunakan merupakan suatu proksi dari adanya suatu tekanan, kesempatan, dan rasionalisasi, maka penelitian ini menggunakan dasar teori Fraud Triangle. Penelitian ini dilakukan dengan menarik kesimpulan dari pendapat para pegawai negeri yang bekerja di sektor pemerintahan dinas kesehatan untuk mengetahui kecenderungan terjadinya fraud. Beberapa faktor yang mempengaruhi kecenderungan terjadinya fraud terdiri dari keefektifan pengendalian internal, kepuasan kompensasi, kultur organisasi, perilaku tidak etis, dan gaya kepemimpinan.

Berdasarkan latar belakang di atas, maka dapat dirumuskan masalah dalam penelitian ini, yaittu apakah keefektifan sistem pengendalian internal, kesesuaian kompensasi, kultur organisasi, perilaku tidak etis, dan gaya kepemimpinan berpengaruh terhadap faud. Tujuan penelitian ini adalah untuk mengetahui pengaruh keefektifan sistem pengendalian internal, kesesuaian kompensasi, kultur organisasi, perilaku tidak etis, dan gaya kepemimpinan terhadap fraud. Manfaat 
penelitian yang diharapkan adalah penelitian ini dapat dijadikan sebagai bahan evaluasi dan saran bagi Dinas Kesehatan Kota Pontianak terkait sistem dan perilaku yang mempengaruhi kecurangan yang terjadi. Penelitian ini juga diharapkan dapat memberikan kontribusi bagi pengembangan teori dan dapat dijadikan sebagai acuan untuk penelitian selanjutnya.

\section{Landasan Teori \\ Fraud}

Terdapat dua jenis kesalahan yang dikenal dalam akuntansi yakni kekeliruan (error) dan kecurangan (fraud), dimana perbedaan dari kedua jenis kesalahan ini sangat tipis, yakni ada atau tidak adanya unsur kesengajaan. Seringkali kecurangan lebih sulit untuk dideteksi dibandingkan dengan kekeliruan akibat dari pihak manajemen atau karyawan yang berusaha untuk menyembunyikan kecurangan tersebut.

Menurut Surat Edaran Bank Indonesia Nomor 13/28/DPNP tanggal 09 Desember 2011, fraud adalah tindakan penyimpangan yang sengaja dilakukan untuk megelabui, menipu atau memanipulasi bank, nasabah, atau pihak lain, yang terjadi di lingkungan Bank dan/atau menggunakan sarana Bank sehingga mengakibatkan bank, nasabah, atau pihak lain menderita kerugian dan/atau pelaku fraud memperoleh keuntungan baik secara langsung maupun tidak langsung.

Fraud memiliki empat kriteria, yaitu:

1. Tindakan tersebut dilakukan secara sengaja;

2. Adanya korban;

3. Korban menuruti kemauan pelaku;

4. Adanya kerugian yang dialami oleh korban.

Menurut The Association of Certified Fraud Examiners (ACFE), fraud diklasifikasikan menjadi tiga, yaitu: Finacial Statement Fraud, Asset Misappropriation, dan Corruption.

\section{Sistem Pengendalian Internal}

Menurut Ikatan Akuntansi Indonesia (IAI), pengendalian internal adalah suatu proses yang dijalankan oleh dewan komisaris, manajemen, dan personil lain entitas yang didesain untuk memberikan keyakinan memadai tentang pencapaian tiga golongan tujuan berikut ini: (a) keandalan pelaporan keuangan, (b) efektivitas dan efisiensi operasi, dan (c) kepatuhan terhadap hukum dan peraturan yang berlaku.

Sistem pengendalian internal bagi sebuah organisasi sangatlah penting, yakni untuk memberikan perlidungan bagi entitas terhadap kelemahan manusia serta untuk mengurangi kemungkinan kesalahan dan tindakan yang tidak sesuai dengan peraturan (Wilopo, 2006). Maka semakin baik pengendalian internal, maka semakin rendah tingkat terjadinya kecurangan akuntansi. Menurut Arens \& Loebbecke (2009:258) dalam perancangan struktur pengendalian internal bertujuan sebagai keandalan laporan keuangan, mendorong efektivitas dan efisiensi operasional, dan ketaatan pada hukum dan peraturan.

Struktur pengendalian internal memiliki lima komponen (COSO dalam Afsari 2016):

1. Lingkungan pengendalian (Control Environment);

2. Penaksiran Risiko (Risk Assessment);

3. Aktivitas Pengendalian (Control Activities);

4. Informasi dan Komunikasi (Information and Communication);

5. Pemantaun (Monitoring).

\section{Kesesuaian Kompensasi}

Mangkupawira (2002:196) dalam Afsari (2016), menyatakan bahwa kompensasi merupakan bentuk pembayaran tunai langsung atau tidak langsung dalam bentuk manfaat bagi karyawan dan intensif yang memotivasi karyawan bekerja keras dalam mencapai produktivitas kerja yang semakin tinggi.

Berdasarkan definisi diatas dapat disimpulkan bahwa kompensasi adalah sesuatu yang diterima secara periodik oleh karyawan sebagai balasan dari pekerjaan yang telah dikontribusikan terhadap perusahaannya. Kompensasi atau gaji berperan dalam meningkatkan motivasi karyawan 
untuk bekerja lebih efektif, meningkatkan produktivitas dalam perusahaan, meningkatkan kinerja, dan mengimbangi kekurangan dan keterlibatan komitmen pekerja. Faktor-faktor yang mempengaruhi tingkat kompensasi menurut Mangkunegara (2001:84), yaitu:

1. Faktor Pemerintah (Government Factors);

2. Penawaran Bersama Antara Perusahaan (Collective Bargaining);

3. Standar dan Biaya Hidup Karyawan (Standard and Cost in Living);

4. Ukuran Perbandingan Upah;

5. Permintaan dan Persediaan (Supply and Demand);

6. Kemampuan Membayar (Ability to Pay).

Menurut Flippo yang dikutip Handoko (2001:56), kompensasi berdasarkan jenisnya dibagi menjadi tiga, yaitu: kompensasi langsung, kompensasi tidak langsung, dan kompensasi non finansial. Apabila kompensasi yang diberikan tidak sesuai, dapat mengakibatkan berkurangnya antusias dan ambisi untuk bekerja dan bersaing, sehingga hal ini menyebabkan turunnya nilai sumber daya manusia pada perusahaan tersebut.

\section{Kultur Organisasi}

Menurut Davis (1984), budaya organisasi merupakan pola keyakinan dan nilai-nilai organisasional yang dipahami, dijiwai, dan dipraktikkan oleh anggota organisasi. Pola tersebut akan membentu perilaku para anggota organisasi dalam bertindak dan berperilaku.

Menurut Robbins (2003), budaya organisasi adalah sistem makna bersama atau seperangkat karakteristik utama yang dianut dan dihargai oleh anggota organisasi yang membedakan suatu organisasi dari organisasi lain. Budaya organisasi tidak berkaitan dengan apakah karyawan menyukai budaya atau tidak, namun berkaitan dengan bagaimana karyawan mempersepsikan karakteristik dari budaya organisasinya.

Kultur organisasi mempunyai peran yang penting, yaitu sebagai penentu arah organsisasi yang menentukan hal yang boleh atau tidak boleh dilakukan, pengeloaan dan pengalokasian sumber daya organisasi yang baik, serta sebagai alat untuk menghadapi peluang dan masalah yang dapat muncul dari lingkungan internal dan eksternal.

\section{Perilaku Tidak Etis}

Etis merupakan asas perilaku yang disepakati dan dilakukan secara umum, terkait hal-hal seperti moral, sesuatu yang benar dan bermartabat. Buckley et al (1998) dalam Wilopo 2006, menjelaskan bahwa perilaku tidak etis merupakan sesuatu yang sulit untuk dimengerti, dikarenakan hal ini terkait dengan adanya hubungan yang rumit antara situasi dengan karakteristik pribadi pelakunya.

Menurut Wilopo (2008), pribadi seseorang menentukan terjadinya kecurangan akuntansi. Organisasi yang memiliki standar etika yang rendah akan memiliki risiko kecurangan akuntansi yang tinggi sehingga menyebabkan seseorang berperilaku tidak etis seperti penyalahgunaan wewenang, kekuasaan, kedudukan, dan sumber daya. Dengan demikian, dibutuhkan perilaku yang etis dari diri manajemen organisasi sehingga dapat tercipta lingkungan organisasi yang etis. Karyawan akan lebih cenderung menaati peraturan yang telah ditetapkan serta menghindari perbuatan curang yang dapat merugikan perusahaan.

\section{Gaya Kepemimpinan}

Menurut Miftah Thola (2010:49), definisi gaya kepemimpinan adalah: "Gaya kepemimpinan merupakan norma perilaku yang digunakan oleh seseorang pada saat orang tersebut mencoba mempengaruhi perilaku orang lain atau bawahan."

Menurut Kartini Kartono (2008:34), gaya kepemimpinan memiliki definisi: "Gaya kepemimpinan adalah sifat, kebiasaan, tempramental, watak, dan kepribadian yang membedakan seorang pemimpin dalam berinteraksi dengan orang lain."

Menurut House (1971) dalam Zulkarnain (2013), gaya kepemimpinan diidentifikasikan sebagai:

1. Kepemimpinan yang direktif (mengarahkan);

2. Kepemimpinan yang suportif (mendukung);

3. Kepemimpinan partisipatif; 
4. Kepemimpinan yang berorientasi pada pencapaian.

Indikator gaya kepemimpinan menurut Kartini Kartono (2008:34), adalah: sifat, kebiasaan, tempramen, watak, dan kepribadian.

\section{Penelitian Terdahulu}

Berdasarkan hasil penelitian di atas, terdapat adanya perbedaan hasil penelitian yang dilakukan oleh banyak peneliti. Salah satu faktor yang mempengaruhi fraud adalah keefektifan sistem pengendalian internal. Penelitian yang dilakukan Mustikasari (2013 menunjukkan bahwa pengendalian internal berpengaruh negatif terhadap fraud. Artinya, sistem pengendalian internal yang baik dapat mencegah terjadinya tindakan kecurangan. Hasil penelitian Mustikasari ini bertentangan dengan penelitian yang dilakukan oleh Tiro (2014). Menuut Tiro (2014), sistem pengendalian internal berpengaruh positif terhadap fraud.

Selain sistem pengendalian internal, faktor lainnya adalah kesesuaian kompensasi. Penelitian yang dilakukan oleh Mustikasari (2013), menunjukkan bahwa kesesuaian kompensasi berpengaruh negatif terhadap fraud. Apabila seseorang merasa cukup dan puas dengan imbalan yang diberikan dari perusahaan, kecil kemungkinan terjadi tindakan kecurangan. Hasil penelitian ini tidak didukung oleh Afsari (2016), yang menyatakan bahwa kesesuaian kompensasi berpengaruh positif terhadap fraud. Di sisi lain, Ramdhana (2015) dan Usman (2017) menyatakan bahwa fraud tidak dipengaruhi oleh kesesuaian kompensasi.

Kultur organisasi merupakan salah satu faktor yang mempengaruhi fraud dimana menurut Widyasari, Yuniarta, dan Sujana (2017), kultur organisasi berpengaruh negatif terhadap fraud. Jika kultur organisasi yang dimiliki semakin baik, maka akan mencegah terjadinya fraud. Dengan kata lain, organisasi yang menjunjung tinggi kejujuran dan perilaku yang bermoral secara tidak langsung akan mempengaruhi karyawan dalam berperilaku baik terhadap organisasinya. Akan tetapi, Sudibyo (2016) menyatakan bahwa kultur organisasi berpengaruh positif terhadap fraud.

Selain kultur organisasi, perilaku tidak etis juga menjadi salah satu faktor yang mendorong tindakan kecurangan akuntansi oleh karyawan. Menurut Ramdhana (2015), perilaku tidak etis berpengaruh positif terhadap fraud. Artinya, seseorang yang memiliki etika yang rendah memiliki risiko kecurangan akuntansi yang tinggi. Akan tetapi, terdapat perbedaan menurut Afsari (2016), bahwa perilaku tidak etis tidak berpengaruh terhadap kecurangan akuntansi yang terjadi.

Gaya kepemimpinan merupakan salah satu faktor yang mempengaruhi kecurangan akuntansi dimana menurut Pramudita (2013) dan Sudibyo (2016), bahwa gaya kepemimpinan berpengaruh negatif terhadap fraud. Pemimpin yang mempunyai tingkah laku atau kepribadian yang mau memotivasi dan mendorong karyawan untuk mau mencapai tujuan organisasi yang telah ditetapkan bersama dapat meminimalisir terjadinya fraud. Sebaliknya, Asari (2016) berpendapat bahwa gaya kepemimpinan tidak berpengaruh terhadap fraud.

\section{Kerangka Konseptual}

\section{Pengembangan Hipotesis}

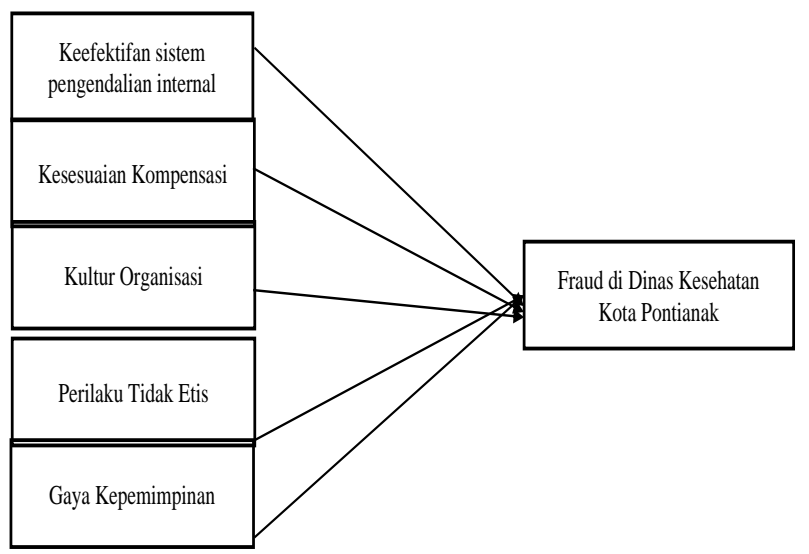

Gambar 1. Kerangka Konseptual 
Kecurangan dapat terjadi apabila terdapat peluang untuk melakukan tindakan tersebut, terlebih jika muncul peluang yang besar maka kecurangan akuntansi lebih sering terjadi. Peluang tersebut dapat dikurangi dengan terciptanya pengendalian internal yang efektif, sehingga dapat menurunkan tingkat kecurangan yang terjadi, begitu juga sebaliknya apabila organisasi memiliki kualitas pengendalian yang buruk, maka hal itu akan memberikan kesempatan bagi karyawan untuk melakukan kecurangan.

$\mathrm{H}_{1}$ : Keefektifan sistem pengendalian internal berpengaruh negatif terhadap fraud

di Dinas Kesehatan Kota Pontianak.

Kesesuaian kompensasi dirancang sedemikian rupa agar mampu memenuhi kebutuhan karyawan sehingga dapat meningkatkan kinerja pegawai dan mengurangi kecurangan yang terjadi. Apabila kompensasi yang diterima dianggap tidak sepadan dengan kontribusi yang telah diberikan, maka hal tersebut dapat mendorong karyawan untuk melakukan tindakan kecurangan demi keuntungan prbadi. Oleh karena itu, kompensasi berpengaruh terhadap kinerja karyawan dan dapat meminimalisir terjadinya tindakan kecurangan.

$\mathrm{H}_{2}$ : Kesesuaian kompensasi berpengaruh negatif terhadap fraud di Dinas Kesehatan Kota Pontianak.

Budaya organisasi yang baik dapat menciptakan motivasi dalam tiap karyawan sehingga mempengaruhi kinerja yang dihasilkan. Nilai-nilai dan perilaku yang dianut bersama membuat karyawan merasa nyaman dan memiliki komitmen yang kuat untuk memajukan organisasi. Oleh karena itu, budaya organisasi membentuk karyawan organisasi untuk memiliki sense of belonging dan sense of identity yang dapat menekan risiko terjadinya fraud. Dapat dikatakan bahwa baik atau tidaknya suatu budaya organisasi berpengaruh terhadap tindakan kecurangan yang terjadi, semakin baik budaya organisasi yang dimiliki maka akan menurunkan tindakan kecurangan.

$\mathrm{H}_{3}$ : Kultur organisasi berpengaruh negatif terhadap fraud di Dinas Kesehatan

Kota Pontianak.

Perilaku tidak etis sulit untuk diukur dikarenakan terkait hubungannya dengan karakteristik pribadi pelaku kecurangan. Perilaku tidak etis yang dilakukan terdiri dari perilaku yang menyalahgunakan kedudukan maupun kekuasaan, menyalahgunakan wewenang maupun otoritas, menyalahgunakan alokasi penggunaan sumber daya organisasi, dan penipuan. Perilaku tidak etis berpengaruh positif terhadap kecurangan (fraud).

$\mathrm{H}_{4}$ : Perilaku tidak etis berpengaruh positif terhadap fraud di Dinas Kesehatan Kota Pontianak.

Perilaku karyawan dapat terbentuk dari cara pemimpin memberikan motivasi maupun memimpin karyawannya dalam mencapai tujuan dan sasaran organisasi. Oleh karena itu, gaya kepemimpinan yang dimiliki harus tepat. Gaya kepemimpinan yang tepat seperti memberikan motivasi kepada karyawannya melalui promosi, reward, maupun promosi jabatan yang sesuai dapat mendorong karyawan untuk mengikuti setiap peraturan perusahaan. Dengan gaya kepemimpinan yang tepat dan baik, akan mencegah terjadinya tindakan kecurangan yang terjadi pada perusahaan.

$\mathrm{H}_{5}$ : Gaya kepemimpinan berpengaruh negatif terhadap fraud di Dinas Kesehatan

Kota Pontianak.

\section{METODE}

Populasi dalam penelitian ini adalah seluruh pegawai tetap/pegawai negeri sipil (PNS) yang bekerja di Dinas Kesehatan Kota Pontianak. Dalam penelitian ini digunakan teknik pengambilan sampel convenience sampling yaitu penarikan sampel berdasarkan keinginan peneliti sesuai dengan tujuan penelitian dengan mengumpulkan informasi yang dibutuhkan untuk penelitian. Sampel yang diambil sebanyak 85 Pegawai Negeri Sipil (PNS).

Variabel-variabel yang digunakan dalam penelitian ini dapat dirangkum dalam tabel berikut ini:

Tabel 1. Operasional Variabel 


\begin{tabular}{|c|c|c|c|}
\hline $\begin{array}{c}\text { Jenis } \\
\text { Variabel }\end{array}$ & $\begin{array}{l}\text { Variabel dan } \\
\text { Definisi }\end{array}$ & Indikator & Skala \\
\hline \multirow[t]{6}{*}{$\begin{array}{l}\text { Variabel } \\
\text { Independen }\end{array}$} & $\begin{array}{l}\text { Keefektifan Sistem } \\
\text { Pengendalian } \\
\text { Internal }\left(\mathbf{X}_{\mathbf{1}} \mathbf{)}\right. \\
\text { Keefektifan sistem } \\
\text { pengendalian internal } \\
\text { merupakan persepi } \\
\text { karyawan mengenai } \\
\text { keefektifan proses } \\
\text { yang diterapkan dan } \\
\text { dijalankan dalam } \\
\text { perusahannya yang } \\
\text { tercermin dari } \\
\text { tercapainya tujuan } \\
\text { perusahaan dalam } \\
\text { memberikan } \\
\text { keyakinan memadai } \\
\text { mengenai efektivitas } \\
\text { dan efisiensi operasi, } \\
\text { keandalan laporan } \\
\text { keuangan, dan } \\
\text { kepatuhan terhadap } \\
\text { hukum dan peraturan } \\
\text { yang berlaku. }\end{array}$ & 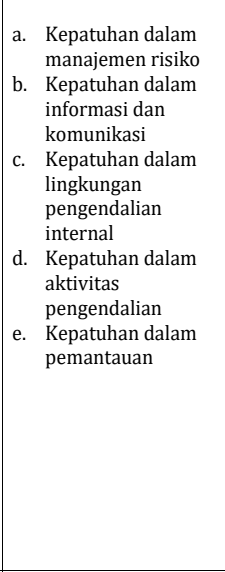 & $\begin{array}{l}\text { Skala } \\
\text { Likert }\end{array}$ \\
\hline & \begin{tabular}{|l} 
Kepuasan \\
Kompensasi $\left(\mathbf{X}_{2}\right)$ \\
Kepuasan \\
kompensasi adalah \\
persepi karyawan \\
tentang sesuatu yang \\
diberikan oleh \\
perusahaan yang \\
sebanding dengan \\
kontribusi karyawan \\
terhadap perusahaan \\
tersebut.
\end{tabular} & \begin{tabular}{|ll} 
a. & Kompensasi \\
& keuangan \\
b. & Pengakuan \\
& perusahaan atas \\
& keberhasilan dalam \\
& melaksanakan \\
& pekerjaan. \\
c. & Promosi \\
d. & Penyelesaian tugas \\
e. & Pencapaian sasaran
\end{tabular} & $\begin{array}{l}\text { Skala } \\
\text { Likert }\end{array}$ \\
\hline & \begin{tabular}{|l|} 
Kultur Organisasi \\
$(\mathbf{X} 3)$ \\
Kultur organisasi \\
merupakan nilai atau \\
norma yang \\
mengarahkan \\
perilaku setiap \\
karyawan dan akan \\
menjadi dasar aturan \\
\end{tabular} & 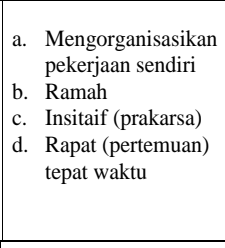 & $\begin{array}{l}\text { Skala } \\
\text { Likert }\end{array}$ \\
\hline & $\begin{array}{l}\text { Perilaku Tidak Etis }\left(\mathbf{X}_{4}\right) \\
\text { Perilaku tidak etis } \\
\text { merupakan perilaku yang } \\
\text { menyalahgunakan jabatan, } \\
\text { posisi, } \\
\text { wewenang/kekuasaan yang } \\
\text { dimiliki untuk melakukan } \\
\text { perbuatan yang hanya } \\
\text { menguntungkan diri } \\
\text { sendiri. }\end{array}$ & 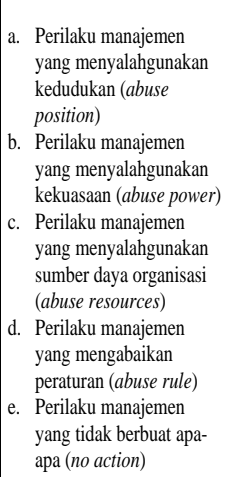 & $\begin{array}{l}\text { Skala } \\
\text { Likert }\end{array}$ \\
\hline & $\begin{array}{l}\text { Gaya Kepemimpinan } \\
\left(\mathbf{X}_{\mathbf{5}}\right) \\
\text { Gaya kepemimpinan } \\
\text { adalah persepsi karyawan } \\
\text { mengenai pemimpinnya } \\
\text { yang dapat mempengaruhi } \\
\text { bawahan agar dapat } \\
\text { berantusias dan berrsama- } \\
\text { sama mencapai tujuan } \\
\text { kelompok. }\end{array}$ & $\begin{array}{l}\text { a. Relasi pimpinan dengan } \\
\text { bawahan } \\
\text { b. Struktur tugas } \\
\text { c. Posisi kekuatan } \\
\text { d. Delegasi tugas } \\
\text { e. Etika pemimpin }\end{array}$ & $\begin{array}{l}\text { Skala } \\
\text { Likert }\end{array}$ \\
\hline & $\begin{array}{l}\text { Fraud }(\mathbf{Y}) \\
\text { Fraud pada sektor } \\
\text { pemerintahan adalah } \\
\text { persepsi pegawai di } \\
\text { instansi pemerintahan } \\
\text { mengenai tindak } \\
\text { kecurangan yang terjadi } \\
\text { yaitu korupsi. }\end{array}$ & $\begin{array}{l}\text { a. Sisi pemalsuan } \\
\text { pencatatan } \\
\text { b. Penerimaan barang } \\
\text { c. Pencurian asset } \\
\text { perusahaan untuk } \\
\text { kepentingan pribadi } \\
\text { d. Penggelapan uang } \\
\text { e. Suap. }\end{array}$ & \begin{tabular}{|l} 
Skala \\
Likert
\end{tabular} \\
\hline
\end{tabular}

Metode pengumpulan data pada penelitian ini adalah survei dengan menyebarkan kuisioner. Sumber data yang digunakan adalah data primer. Penelitian ini menggunakan teknik analisis 
deskriptif untuk pengenalan data dan analisis regresi linier berganda untuk menguji hipotesis yang diajukan.

Adapun persamaan regresi linier berganda dalam penelitian ini dapat ditulis sebagai berikut:

$$
\mathrm{Y}=\alpha+\beta_{1} \mathrm{x}_{1}+\beta_{2} \mathrm{x}_{2}+\beta_{3} \mathrm{X}_{3}+\beta_{4} \mathrm{x}_{4}+\beta_{5} \mathrm{x}_{5}+\mathrm{e}
$$

Keterangan:

$$
\begin{array}{ll}
\mathrm{Y} & =\text { Fraud }(\mathrm{K}) \\
\alpha & =\text { Konstanta } \\
\beta 1, \beta 2, \beta_{3}, \beta_{4}, \beta_{5} & =\text { Koefisien Regresi } \\
\mathrm{X}_{1} & =\text { Keefektifan Sistem Pengendalian Internal (KSPI) } \\
\mathrm{X}_{2} & =\text { Kesesuaian Kompensasi (KK) } \\
\mathrm{X}_{3} & =\text { Kultur Organisasi (KuO) } \\
\mathrm{X}_{4} & =\text { Perilaku Tidak Etis (PTE) } \\
\mathrm{X}_{5} & =\text { Gaya Kepemimpinan (GK) } \\
\mathrm{e} & =\text { Kesalahan regresi (error) }
\end{array}
$$

\section{HASIL DAN PEMBAHASAN}

\section{Deskripsi Objek Penelitian}

Dari hasil deskripsi data yang dilakukan, menunjukkan bahwa responden terbanyak aalah pria dengan jumlah 46 atau 54,1\%, rentang umur 31-40 sebanyak 34 atau $40 \%$, pendidikan terakhir S2 sebanyak 49 atau $57,6 \%$, lamanya bekerja sebanyak 2-10 tahun atau $54,1 \%$.

\section{Statistik Deskriptif}

Statistik deskriptif memberikan deskripsi atau gambaran suatu data yang dapat dilihat dari nilai rata-rata (mean), standar deviasi, varians, maksimum, minimum, sum, range, dan lain-lain (Ghozali, 2011:19). Berikut hasil dari uji statistik deskriptif:

\section{Pemilihan Model Regresi}

Dalam melakukan analisis regresi linier berganda, perlu dilakukan uji validitas, uji reliabilitas, uji normalitas, uji multikolinearitas, uji heteroskedastisitas, uji t, uji F, uji koefisien determinasi.

\section{Uji Kualitas Data}

\section{Uji Validitas}

Pengujian validitas dilakukan berdasarkan analisis item yaitu mengkorelasikan skor setiap item dengan skor variabel (hasil penjumlahan seluruh skor item pertanyaan). Teknik korelasi yang digunakan adalah Pearson Correlation. Item pertanyaan dinyatakan valid apabila memiliki nilai rhitung $>r_{\text {tabel. }}$. Hasil uji validitas dengan metode Pearson Correlation, berikut:

Tabel 2. Uji Validitas

\begin{tabular}{ccccc}
\hline Variabel & Butir & r hitung & r tabel & Ket \\
\hline \multirow{6}{*}{ KSPI } & Item 1 & 0,668 & 0,22 & Valid \\
& Item 2 & 0,788 & 0,22 & Valid \\
& Item 3 & 0,753 & 0,22 & Valid \\
& Item 4 & 0,733 & 0,22 & Valid \\
& Item 5 & 0,589 & 0,22 & Valid \\
& Item 6 & 0,674 & 0,22 & Valid \\
& Item 7 & 0,496 & 0,22 & Valid \\
& Item 1 & 0,768 & 0,22 & Valid \\
& Item 2 & 0,680 & 0,22 & Valid \\
KK & Item 3 & 0,723 & 0,22 & Valid \\
& Item 4 & 0,725 & 0,22 & Valid \\
& Item 5 & 0,683 & 0,22 & Valid \\
& Item 6 & 0,770 & 0,22 & Valid
\end{tabular}




\begin{tabular}{ccccc}
\multirow{4}{*}{ KuO } & Item 1 & 0,731 & 0,22 & Valid \\
& Item 2 & 0,743 & 0,22 & Valid \\
& Item 3 & 0,753 & 0,22 & Valid \\
& Item 4 & 0,837 & 0,22 & Valid \\
& Item 5 & 0,852 & 0,22 & Valid \\
& Item 6 & 0,673 & 0,22 & Valid \\
& Item 1 & 0,757 & 0,22 & Valid \\
& Item 2 & 0,828 & 0,22 & Valid \\
PTE & Item 3 & 0,786 & 0,22 & Valid \\
& Item 4 & 0,751 & 0,22 & Valid \\
& Item 5 & 0,686 & 0,22 & Valid \\
& Item 1 & 0,584 & 0,22 & Valid \\
& Item 2 & 0,535 & 0,22 & Valid \\
& Item 3 & 0,642 & 0,22 & Valid \\
GK & Item 4 & 0,622 & 0,22 & Valid \\
& Item 5 & 0,659 & 0,22 & Valid \\
& Item 6 & 0,703 & 0,22 & Valid \\
& Item 7 & 0,514 & 0,22 & Valid \\
& Item 1 & 0,483 & 0,22 & Valid \\
& Item 2 & 0,634 & 0,22 & Valid \\
& Item 3 & 0,704 & 0,22 & Valid \\
& Item 4 & 0,678 & 0,22 & Valid \\
& Item 5 & 0,639 & 0,22 & Valid \\
& Item 6 & 0,669 & 0,22 & Valid \\
& Item 7 & 0,640 & 0,22 & Valid \\
\hline \multirow{6}{*}{ PH }
\end{tabular}

Diperoleh nilai $r_{\text {hitung }}$ dari semua item pada validitas $>r_{\text {tabeel }}$, maka butir-butir instrumen penelitian tersebut dinyatakan valid, sehingga pertanyaan-pertanyaan yang tertuang dalam angket penelitian dapat digunakan dalam penelitian.

2. Uji Reliabilitas

Reliabilitas berarti jika jawaban seseorang terhadap pertanyaan adalah konsisten atau stabil dari waktu ke waktu. Pengujian reliabilitas dalam penelitian ini dilakukan dengan menghitung besarnya nilai Cronbach's Alpha instrumen dari masing-masing variabel yang diuji. Apabila nilai Cronbach's Coefficient Alpha lebih besar dari 0,60, maka jawaban dari para responden pada kuesioner sebagai alat pengukur dinilai dinyatakan reliabel. Hasil uji reliabilitas dapat dilihat pada table berikut:

Tabel.3 Uji Reliabilitas

\begin{tabular}{ccc}
\hline Variabel & AlphaCronbach & Keterangan \\
\hline KSPI & 0,802 & Reliabel \\
KK & 0,782 & Reliabel \\
KuO & 0,792 & Reliabel \\
PTE & 0,796 & Reliabel \\
GK & 0,745 & Reliabel \\
K & 0,756 & Reliabel \\
\hline
\end{tabular}

Berdasarkan Tabel diatas, diperoleh nilai nilai AlphaCronbach dari semua variabel penelitian yaitu menunjukkan lebih besar dari nilai 0,6. Dengan demikian jawaban-jawaban responden dari variabel-variabel penelitian tersebut reliabel.

\section{Uji Asumsi Klasik}

\section{Uji Normalitas}


Uji Normalitas data bertujuan untuk menguji apakah dalam model regresi, variabel dependen maupun independen mempunyai distribusi normal atau tidak. Model regresi yang baik memiliki distribusi normal atau mendekati normal.

\section{Uji Multikolinearitas}

Multikolinearitas bertujuan untuk menguji apakah dalam model regresi ditemukan adanya korelasi antar variabel bebas. Pengujian adanya multikolinearitas dilakukan dengan memperhatikan besarnya tolerance value dan besarnya VIF (Ghozali, 2005). Jika nilai tolerance value $>0,10$ atau < 1 dan VIF $<10$, maka tidak terjadi multikolinearitas. Hasil uji multikolinearitas ditunjukkan pada tabel berikut:

Tabel 4. Uji Multikolinearitas

\begin{tabular}{llll}
\hline \multicolumn{3}{c}{ Coefficients $^{\mathbf{a}}$} \\
\hline Model & & \multicolumn{2}{c}{ Collinearity } \\
Statistics \\
\cline { 3 - 4 } & & Tolerance & VIF \\
\hline \multirow{3}{*}{1} & (Constant) & & \\
\cline { 2 - 4 } & KSPI &, 894 & 1,118 \\
& KK &, 963 & 1,038 \\
& KuO &, 892 & 1,121 \\
& PTE &, 986 & 1,014 \\
& GK &, 949 & 1,054 \\
\hline
\end{tabular}

Berdasarkan tabel diatas menunjukkan bahwa seluruh variabel yaitu KSPI, KK, KuO, PTE, dan GK dengan nilai VIF (Variance Inflation Factor) adalah < 10. Sedangkan untuk nilai Tolerance KSPI, KK, KuO, PTE, dan GK yaitu > 0,10 atau < 1. Jadi berdasarkan nilai VIF (Variance Inflation Factor) dan Tolerance dapat disimpulkan bahwa model regresi tidak mengandung multikolinearitas.

\section{Uji Heteroskedastisitas}

Heteroskedastisitas muncul ketika varian dari distribusi probabilitas gangguan tidak konstan untuk seluruh pengamatan atas variabel penelitian. Metode yang digunakan untuk menguji heteroskedastisitas dalam penelitian ini memakai diagram scatterplot. Hasil uji heteroskedastisitas dapat ditunjukkan pada gambar sebagai berikut:

Gambar 2. Uji Heteroskedastisitas

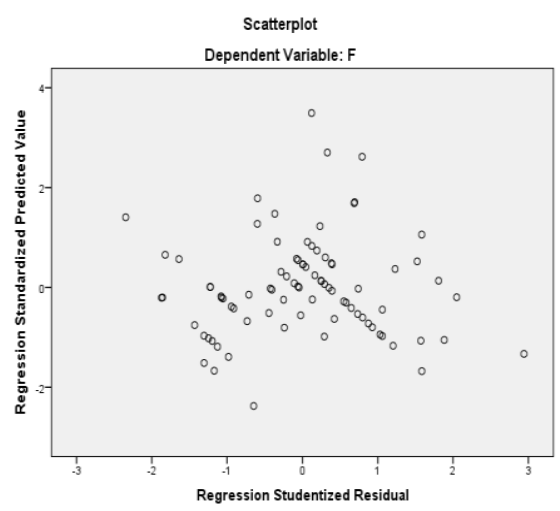

Melalui grafik scatter plot pada gambar diatas maka dapat dilihat pola penyebaran data yang ada. Pola penyebaran data yang berupa titik-titik pada scatter plot menyebar di atas dan di bawah dan penyebarannya tidak membentuk pola tertentu, sehingga dari pola penyebaran ini dapat disimpulkan bahwa tidak terjadi heteroskedastisitas.

\section{Uji Hipotesis}

\section{Analisis Regresi Berganda}


Model regresi linier berganda digunakan untuk mengetahui pengaruh variabel bebas terhadap variabel independen. Hasil perhitungan regresi berganda disajikan pada tabel berikut:

Tabel 5. Analisis Regresi Linier Berganda

\begin{tabular}{|c|c|c|c|c|c|c|}
\hline \multicolumn{7}{|c|}{ Coefficients $^{\mathrm{a}}$} \\
\hline \multirow{2}{*}{\multicolumn{2}{|c|}{ Model }} & \multicolumn{2}{|c|}{$\begin{array}{l}\text { Unstandardized } \\
\text { Coefficients }\end{array}$} & \multirow{2}{*}{\begin{tabular}{|c|}
$\begin{array}{c}\text { Standardized } \\
\text { Coefficients }\end{array}$ \\
Beta \\
\end{tabular}} & \multirow[t]{2}{*}{$t$} & \multirow[t]{2}{*}{ Sig. } \\
\hline & & $\mathrm{B}$ & Std. Error & & & \\
\hline \multirow{6}{*}{1} & (Constant) & 27,500 & 4,773 & & 5,761 & .000 \\
\hline & KSPI &,- 176 &, 076 &,- 222 & $-2,322$ &, 023 \\
\hline & $\mathrm{KK}$ &,- 301 &, 089 &,- 309 & $-3,359$ &, 001 \\
\hline & $\mathrm{KuO}$ &,- 160 &, 083 &,- 185 & $-1,930$ &, 057 \\
\hline & PTE & 309 & 091 & 309 & 3,397 &, 001 \\
\hline & GK &,- 033 & 103 &,- 030 & -320 & 750 \\
\hline
\end{tabular}

Dari tabel diatas menunjukkan bahwa persamaan regresi ganda yang diperoleh dari hasil analisis adalah

$$
Y=27,500-0,176 X_{1}-0,301 X_{2}-0,160 X_{3}+0,309 X_{4}-0,033 X_{5}
$$

\section{Uji-t}

Uji statistik t pada dasarnya menunjukkan seberapa jauh pengaruh satu variabel bebas secara individual dalam menerangkan variasi variabel terikat. Hasil uji t-test dapat ditunjukkan pada Tabel 5 diatas.

Berdasarkan Tabel 5 diatas, nilai $\mathrm{b}_{1}$ adalah $-0,176$ yang menunjukkan hubungan keefektifan sistem pengendalian internal dengan fraud memiliki hubungan yang negative dan diperoleh nilai pvalue hasil uji-t dari variabel keefektifan sistem pengendalian internal sebesar 0,023 . Dikarenakan nilai $p$-value lebih kecil dari tingkat signifikan $\alpha=5 \%$ atau $(0,023<0,05)$, maka Ho ditolak dan H1 diterima yang berarti keefektifan sistem pengendalian internal berpengaruh negatif dan signifikan terhadap fraud.

Berdasarkan Tabel 5 diatas, nilai $b_{2}$ adalah $-0,301$ yang menunjukkan hubungan kesesuaian kompensasi dengan fraud memiliki hubungan yang negatif dan diperoleh nilai p-value hasil uji-t dari variabel kesesuaian kompensasi sebesar 0,001. Dikarenakan nilai p-value lebih kecil dari tingkat signifikan $\alpha=5 \%$ atau $(0,001<0,05)$, maka Ho ditolak dan $\mathrm{H} 2$ diterima yang berarti kesesuaian kompensasi berpengaruh negatif dan signifikan terhadap fraud.

Berdasarkan Tabel 5 diatas, nilai $b_{3}$ adalah $-0,160$ yang menunjukkan hubungan kultur organisasi dengan fraud memiliki hubungan yang negatif dan diperoleh nilai p-value hasil uji-t dari variabel kultur organisasi sebesar 0,057. Dikarenakan nilai $p$-value lebih kecil dari tingkat signifikan $\alpha=5 \%$ atau $(0,057<0,05)$, maka Ho ditolak dan H3 diterima yang berarti kultur organisasi berpengaruh negatif dan signifikan terhadap fraud.

Berdasarkan Tabel 5 diatas, nilai $\mathrm{b}_{4}$ adalah 0,309 yang menunjukkan hubungan perilaku tidak etis dengan fraud memiliki hubungan yang positif dan diperoleh nilai p-value hasil uji-t dari variabel perilaku tidak etis sebesar 0,001. Dikarenakan nilai $p$-value lebih kecil dari tingkat signifikan $\alpha=5 \%$ atau $(0,001<0,05)$, maka Ho ditolak dan $\mathrm{H} 4$ diterima yang berarti perilaku tidak etis berpengaruh positif dan signifikan terhadap fraud.

Berdasarkan Tabel 5 diatas, nilai $b_{5}$ adalah $-0,033$ yang menunjukkan hubungan gaya kepemimpinan dengan fraud memiliki hubungan yang negatif dan diperoleh nilai p-value hasil uji-t dari variabel gaya kepemimpinan sebesar 0,750. Dikarenakan nilai $p$-value lebih besar dari tingkat signifikan $\alpha=5 \%$ atau $(0,750>0,05)$, maka Ho diterima dan H5 ditolak yang berarti gaya kepemimpinan tidak berpengaruh terhadap fraud.

\section{Uji F}

Uji statistik $\mathrm{F}$ digunakan untuk mengetahui apakah semua variabel independen yang dimasukkan ke dalam model mempunyai pengaruh secara bersama-sama terhadap variabel dependen.

Tabel 6. Uji Simultan (Uji F) 


\begin{tabular}{|c|c|c|c|c|c|c|}
\hline \multicolumn{7}{|c|}{ ANOVA $^{a}$} \\
\hline & & $\begin{array}{l}\text { Sum of } \\
\text { Squares }\end{array}$ & $\mathrm{df}$ & $\begin{array}{l}\text { Mean } \\
\text { Square }\end{array}$ & $\mathrm{F}$ & Sig. \\
\hline \multirow{3}{*}{1} & Regression & 299,722 & 5 & 59,944 & 8,688 &, $000^{\mathrm{b}}$ \\
\hline & Residual & 545,102 & 79 & 6,900 & & \\
\hline & Total & 844,824 & 84 & & & \\
\hline
\end{tabular}

Berdasarkan dari hasil perhitungan yang ditunjukkan pada Tabel diatas, diperoleh nilai pvalue hasil uji $\mathrm{F}$ sebesar 0.000. Dikarenakan nilai $\mathrm{p}$ value kecil dari tingkat signifikan $\alpha=5 \%$ atau $(0,000<0,05)$. Jadi, hasil penelitian menunjukkan terdapat pengaruh keefektifan sistem pengendalian internal, kesesuaian kompensasi, kultur organisasi, perilaku tidak etis, dan gaya kepemimpinan terhadap fraud.

\section{Koefisien Determinasi}

Koefisien determinasi digunakan untuk mengetahui seberapa besar kontribusi dari variabel independent terhadap variabel dependen.

Tabel 7. Uji Koefisien Determinasi

\begin{tabular}{|c|c|c|c|c|}
\hline \multicolumn{5}{|c|}{ Model Summary ${ }^{b}$} \\
\hline $\begin{array}{l}\text { Mod } \\
\text { el }\end{array}$ & $\mathrm{R}$ & $\begin{array}{c}\mathrm{R} \\
\text { Square }\end{array}$ & $\begin{array}{l}\text { Adjusted } \\
\text { R Square }\end{array}$ & $\begin{array}{l}\text { Std. Error } \\
\text { of the } \\
\text { Estimate }\end{array}$ \\
\hline 1 & $596^{2}$ & ,355 & 314 & 2,62679 \\
\hline
\end{tabular}

Nilai adjusted $\mathrm{R}$ square $\left(\mathrm{R}^{2}\right)$ sebesar 0.314 menunjukkan bahwa besarnya peran atau kontribusi variabel keefektifan sistem pengendalian internal, kesesuaian kompensasi, kultur organisasi, perilaku tidak etis, dan gaya kepemimpinan menjelaskan variabel fraud sebesar 31,4\% sedangkan sisanya $68,6 \%$ dijelaskan oleh variabel lain diluar kelima variabel independen diatas.

\section{Pembahasan}

\section{Keefektifan Sistem Pengendalian Internal}

Adanya suatu sistem pengendalian intern yang baik oleh instansi maka akan menurunkan tingkat kecurangan yang akan dilakukan, sebaliknya jika kualitas sistem pengendalian intern yang buruk, maka hal itu akan menjadi kesempatan bagi pegawai untuk melakukan fraud pada instansi tersebut. Semakin baik pengendalian intern di dalam suatu instansi akan semakin rendah tingkat terjadinya fraud di sektor pemerintahan Hal ini didukung oleh penelitian yang dilakukan oleh Mustikasari (2013), Pramudita (2013), Ariani, Musmini dan Herawati (2014), Sari, Yuniarta, dan Adiputra (2015), Ramadhana (2015), Sudibyo (2016), bahwa semakin tinggi efektivitas pengendalian internal, maka akan semakin rendaah risiko fraud. Namun, terdapat perbedaan pada penelitian yang dilakukan oleh Afsari (2016), bahwa sistem pengendalian internal tidak berpengaruh terhadap fraud di sektor pemerintahan.

\section{Pengaruh Kesesuian Kompensasi Terhadap Kecenderungan Kecurangan Akuntansi}

Kompensasi merupakan balas jasa yang diberikan kepada karyawan atas kontribusi terhadap perusahaan. Kesesuaian kompensasi dirancang sedemikian rupa agar mampu memenuhi kebutuhan karyawan sehingga dapat meningkatkan kinerja pegawai dan mengurangi kecurangan yang terjadi. Seorang karyawan yang menerima kompensasi dianggap tidak sepadan dengan kontribusi yang telah diberikan, maka hal tersebut dapat mendorong karyawan untuk melakukan tindakan kecurangan demi keuntungan prbadi. Oleh karena itu, kompensasi berpengaruh terhadap kinerja karyawan dan dapat meminimalisir terjadinya tindakan kecurangan. Hal ini sejalan dengan penelitian yang dilakukan oleh 
Mustikasari (2013), Pramudita (2013), dan Sari, Yuniarta, Adiputra (2015), bahwa kesesuaian kompensasi berpengaruh negatif terhadap fraud. Namun, berbeda dengan hasil penelitian yang dilakukan oleh Afsari (2016), bahwa kompensasi berpengaruh positif terhadap fraud. Hasil penelitian oleh Ramadhana (2015) dan Usman (2017) mengungkapkan bahwa kesesuaian kompensasi tidak berpengaruh terhadap fraud.

\section{Pengaruh Kultur Organisasi Terhadap Kecenderungan Kecurangan Akuntansi}

Tindakan manajemen puncak juga mempunyai dampak besar dalam pembentukan kultur organisasi (melalui apa yang dikatakan dan dilakukan) dan seringkali menentukan iklim umum dari perilaku yang dapat diterima dan yang tidak dapat. Dapat disimpulkan bahwa di suatu lingkungan yang mempunyai kultur organisasi yang baik, karyawan akan lebih cenderung menjalankan peraturan-peraturan instansi dan menghindari perbuatan fraud. Jika terdapat kultur organisasi yang tidak baik maka akan mendorong karyawan untuk melakukan tindakan fraud sesuai kultur organisasi dalam instansi tersebut. Hal ini sejalan dengan penelitian yang dilakukan oleh Sudibyo (2016), bahwa budaya organisasi berpengaruh negatif terhadap tindakan kecurangan. Selain itu, menurut Widyaswari, Yuniarta, dan Sujana (2017), mengungkapkan bahwa budaya organisasi berpengaruh terhadap tindakan kecurangan pada organisasi.

\section{Pengaruh Perilaku Tidak Etis Terhadap Kecenderungan Kecurangan Akuntansi}

Griffin dan Ebert (2007:58) menyatakan bahwa perilaku tidak etis adalah perilaku yang tidak sesuai dengan norma-norma sosial yang diterima secara umum, sehubungan dengan tindakan yang bermanfat atau yang membahayakan. Prinsip tersebut menunjukkan sikap dari manajemen dalam mengelola perusahaan. Prinsip tersebut mewakili sikap manajemen dalam mengelola suatu perusahaan atau instansi. Jika perilaku yang ditunjukkan manajemen cenderung tidak etis maka kecenderungan kecurangan akuntansi akan semakin tinggi. Hal ini sejalan dengan penelitian yang dilakukan oleh Ramdhana (2015), bahwa perilaku tidak etis berpengaruh positif terhadap fraud di sektor pemerintahan.

\section{Pengaruh Gaya Kepemimpinan Terhadap Kecenderungan Kecurangan Akuntansi}

Pengaruh negatif tetapi tidak signifikan antara gaya kepemimpinan terhadap fraud dapat diartikan bahwa baik atau tidaknya gaya kepemimpinan seorang manajer tidak mempengaruhi kecenderungan kecurangan yang dilakukan karyawannya. Hal ini dapat dikarenakan perilaku kepemimpinan seorang manajer tidak dijadikan sebagai faktor utama karyawan dalam melakukan kecurangan, hal ini dapat dimungkinkan adanya faktor internal dalam diri karyawan tersebut yang memicu dalam melakukan kecurangan.

\section{KESIMPULAN \\ Simpulan}

Penelitian ini menguji pengaruh keefektifan sistem pengendalian internal, kesesuaian kompensasi, kultur organisasi, perilaku tidak etis, gaya kepemimpinan, penegakan hukum, asimetri informasi, komitmen organisasi berpengaruh terhadap fraud. Kesimpulan dari penelitian ini adalah sebagain berikut:

1. Terdapat pengaruh negatif dan signifikan antara keefektifan sistem pengendalian internal terhadap Fraud pada Dinas Kesehatan Kota Pontianak.2. Terdapat pengaruh negatif dan signifikan antara kesesuaian kompensasi terhadap Fraud pada Dinas Kesehatan Kota Pontianak.

2. Terdapat pengaruh negatif dan signifikan antara kultur organisasi terhadap Fraud pada Dinas Kesehatan Kota Pontianak.

3. Terdapat pengaruh positif dan signifikan antara perilaku tidak etis terhadap Fraud pada Dinas Kesehatan Kota Pontianak.

4. Tidak terdapat pengaruh antara gaya kepemimpinan terhadap Fraud pada Dinas Kesehatan Kota Pontianak. 


\section{Keterbatasan}

Penelitian hanya dilakukan pada DInas Kesehatan Kota Pontianak, sehingga hasil penelitian tidak dapat mencerminkan risiko fraud yang terjadi di sektor pemerintahan Kota Pontianak. Selain itu, penelitian hanya menggunakan 5 variabel independen untuk diteliti.

\section{Implikasi}

Berdasarkan kesimpulan di atas, adapun saran yang diajukan sebagai berikut :

1. Bagi Pemerintah Daerah Kota Pontianak diharapkan dapat meningkatkan efektifitas dalam sistem pengawasan dan mendesain pemberian kompensasi dengan mempertimbangkan nilai integritas di dalam penilaian kerja yang telah dicapai oleh karyawan agar dapat mengurangi kecenderungan kecurangan yang terjadi di Pemerintah Daerah Kota Pontianak.

2. Bagi peneliti selanjutnya diharapkan untuk menggunakan alat ukur tertentu untuk mendeteksi dan menginvestigasi peluang adanya kecenderungan kecurangan yang terjadi di Pemerintahan.

\section{DAFTAR PUSTAKA}

Afsari, Siti Fitriani. 2016. Analisis Faktor-Faktor yang Mempengaruhi Kecenderungan Kecurangan (Fraud) di Sektor Pemerintahan Berdasarkan Teori Fraud Triangle: Persepsi Pegawai Pemerintahan (Studi pada SKPD di Kabupaten Jember). Skripsi: Universitas Jember

AICPA, SAS No.99. 2002. Consideration of Fraud in a Financial Statement Audit. New York: AICPA.

Albrecht, Chad., Mary-Jo Kranacher., and Steve Albercht. 2012. Asset Misappropriation Research White Paper for the Institute for Fraud Prevention

Alison. 2006. Fraud Auditing (Bagian Pertama Dari Dua Tulisan). http://www.reindo.co.id

Allen, Natalie J dan John P. Meyer. 1997. "Commitment in the Workplace, Theory, Research, and Application". United Kingdom : Sage Publication Ltd.

Arens, Loebbecke. 2009. Auditing Pendekatan Terbaru, edisi kedua. Jakarta: Salemba empat.

Ariani dkk. 2014. Analisi Pengaruh Moralitas Individu, Asimetri Informasi, dan Keefektifan Sistem Pengendalian Internal Terhadap Kecenderungan Kecurangan Akuntansi di PDAM Kabupaten Bangli. e-Journal S1 Ak Universitas Pendidikan Ganesha Volume 2 No: 1 Tahun 2014)

Association of Certified Fraud Examiners. 2006, Report to Nation on Occupational Fraud \& Abuse. The Association of Certified Fraud Examiners, Inc.

Bologna, Jack. 1993. Handbook of Corporate Fraud. Boston; Butterworth- Heinemann.

Buckley, M. R., D. S. Wiese M. G. and Harvey, 1998. An Investigation into Dimensions of Unethical Behavior. Journal of Education for Bussiness, 73 (5), pp: 284-290.

Chan, Syafruddin. 2003. Relationship Marketing : Inovasi Pemasaran Yang Membuat Pelanggan Bertekuk Lutut. PT Gramedia Pustaka Utama. Jakarta.

Cressey Donald R.1953. Others people money, A study in the social psychology of Embezzlement. Montclair: Patterson Smith 
COSO. 2004. "Enterprise risk management-integrated framework". Committee of Sponsoring Organizations.

Deal, Terrence. E dan Kennedy, A.A. 1982. Corporate Culture, Reading. Mass. Addison- Wesley.

Fiedler, F. E. 1967. A Theory Of Leadership Effectiveness. New York : McGraw- Hill

Ghozali, Imam. 2001. “Aplikasi Analisis Multivariate dengan Program SPSS”. Semarang: Badan Penerbit Universitas Diponegoro.

Ghozali, Imam dan Fuad. 2008. "Structural Equation Modelling Teori, Konsep, dan Aplikasinya dengan program LISREL 8.80”. Semarang: Badan Penerbit Universitas Diponegoro.

Handoko, Hani, 1993, Dasar-dasar Manajemen Produksi dan Operasi, cetrakan ketujuh, Yogyakarta : BPFE

Handoko, T. Hani. 2001. Manajemen Personalia dan Sumber Daya Manusia. Yogyakarta. BPFE Yogyakarta

Hasibuan, Malayu S.P. 2002. Manajemen Sumber Daya Manusia. Bumi AKsara. Jakarta

Herujito, Yayat M. 2006. Dasar-Dasar Manajemen. PT Grasindo. Jakarta

IAI. 2001. "Standar Profesional Akuntan Publik". Jakarta: Salemba Empat.

Jensen, M dan Meckling W. 1976. Theory of The Firm: Managerial Behavior, Agency Cost And Ownership Structure. Journal of Financial Economics 3: 305-360.

Kartono, Kartini, 2008 : Pemimpin dan Kepemimpinan. Jakarta : PT. Raja Grafindo Persada.

Lestari, L dan Supadmi, N.2017. "Pengaruh Pengendalian Internal, Integritas, dan Asimetri Informasi pada Kecurangan Akuntansi". E-Jurnal Akuntansi Universitas Udayana. Vol.21.No.1. ISSN: 2302-8556.

Mangkunegara, A.P. 2009. Manajemen Sumber Daya Manusia. Bandung: Rosdakarya

Marliani dan Jogi.2015.Persepsi Pengaruh Fraud Triangle Terhadap Pencurian Kas. Business Accounting Review,Vol 3, No.2 Agustus 2015

Montgomery, D.C., 2002, Introduction to Statistical Quality Control 4 Edition, John Wiley \& Sons (Asia) Pte. Ltd., Singapore.

Mustikasari Putri.2013. "Faktor-Faktor yang Mempengaruhi Fraud di Sektor Pemerintahan Kabupaten Batang". Accounting Analysis Journal AAJ 2 (1)

Pramudita, Aditya. 2013. Faktor - Faktor Yang Mempengaruhi Terjadinya Fraud Di Sektor Pemerintahan (Persepsi Pegawai Pada Dinas Se-Kota Salatiga). Skripsi Universitas Negeri Semarang: Semarang.

Ramdhana, Senna Afriaska. 2015. Persepsi Pegawai Mengenai Faktor-Faktor yang Mempengaruhi Kecurangan (Fraud). Skripsi Univeritas Negeri Semarang

Robbins, Stephen P. 2003. Perilaku Organisasi Jilid 1. Edisi 9. Penerjemah Tim Indeks. Jakarta : PT. Indeks, Gramedia Grup.

Robert, J.House.1971. "A path-goal theoryof leader effectiveness". Adminstrative Science Quarterly, Vol. 16: 321 - 339 
Saputra. 2016. Fsktor-Faktor yang Mempengaruhi Terjadinya Fraud Pada Dinas Pengelolaan Kekayaan dan Keuangan Daerah. JOM Fekon Vol.3 No.1

Sari dkk. 2015. Pengaruh Efektifitas Sistem Pengendalan Internal, Ketaatan Aturan Akuntansi, Persepsi Keseusaian Kompensasi dan Implementasi Good Governance Terhadap Kecenderungan Fraud (Studi Empiris Pada SKPD di Kabupaten Tabanan). E-Journal S1 Ak Universitas Pendidikan Ganesha Volume 3 No.1 Tahun 2015

Schein Edgar H. 1991. Psikologi Organisasi.Jakarta: PT Pustaka Binaman Pressindo.

Sudibyo, Tyagita Dianingtyas. 2016. Pengaruh Gaya Kepemimpinan dan Budaya Organisaasi Terhadap Efektivitas Sistem Pengendalian Internal Dalam Mendeteksi Risiko Fraud di PT. Kaltim Industrial Estate. Skripsi Universitas Sanata Dharma

Sutherland, E. H., 1940, "White Collar Criminality", American Sosiological Review, Vol. 5, No. 1, hal. 2-10.

Stephen P. Robbins, 1996.Perilaku Organisasi, Konsep, Kontroversi danAplikasi. Alih Bahasa : Hadyana Pujaatmaka. Edisi Keenam. Penerbit PT.Bhuana Ilmu Populer, Jakarta.

Sulistiyowati, Firma.2007. "Pengaruh Kepuasan Gaji dan Kultur Organisasi Terhadap Persepsi Aparatur Pemerintah Daerah tentang Tindak Korupsi”.Yogyakarta: Universitas Sanata Dharma.

Tang, T. L. P. and Randy K. Chiu, 2003. Income, Money Etic, Pay Satisfaction, Commitment, and Unethical Behavior: Is the Love of Money the Root of Evil for Hong Kong Employees? Journal of Business Ethics, 46, pp: 13-20.

The Institute of Internal Auditors (IIA). 1995. Standard for the professional Practice Internal Auditing. The IIA Research Foundation, Florida.

Tiro, Andi A. Arif. 2014. Pengaruh Pengendalian Internal dan Kompensasi Terhadap Kecenderungan Kecurangan (Fraud) Pada Pemerintahan Kota Palopo. Skripsi Universitas Hassanuddin Makassar

Usman, Syahriani. 2017. Analisis Faktor-Faktor yang Mempengaruhi Terjadinya Fraud di Sektor Pemerintahan (Studi Pada SKPD Kabupaten Lawa Tmur). Skripsi Universitas Islam Ngeri Syarif Hidayatullah Jakarta

Widyaswari dkk. 2017. Pengaruh Keefektifan Pengendalian Internal, Kesesuaian Kompensasi, dan Budaya Organisasi Terhadap Kecenderungan Kecurangan (Fraud) Pada Lembaga Perkreditan Desa (LPD) Se-kecamtan Susut. E-Journal S1 Ak Universitas Pendidikan Ganesha

Wilopo. 2006. "Analisis Faktor-Faktor Yang Mempengaruhi Kecenderungan Kecurangan Akuntansi: Studi pada Perusahaan Publik dan Badan Usaha Milik Negara di Indonesia". Simposium Nasional Akuntansi IX.

Wilopo. 2006.Analisis Faktor-Faktor Yang Mempengaruhi Kecenderungan Kecurangan Akuntansi. Simposium Nasional Akuntansi IX.

Wilopo. 2008. Pengaruh Pengendalian Internal Bi- rokrasi Pemerintah dan Pelaku Tidak Etis Birokrasi terhadap Kecurangan Akuntansi Di Pemerintah Persepsi Auditor Badan Pemeriksa Keuangan. Jurnal Ventura Volume 11 no. 1 April 2008. 
Zulkarnain, Rifqi Mirza. 2013. Analisis Faktor yang Mempengaruhi Terjadinya Fraud di Sektor Pemerintahan (Studi Kasus Pada Dinas Se-Kota Surakarta). Skripsi: Universitas Negeri Semarang.

, Peraturan Pemerintah No.60 Tahun 2008 Tentang System Pengendalian Internal.

Surat Edaran Bank Indonesia No.13/28/DPNP tanggal 9 Desember 2011 perihal Penerapan Strategi Anti Fraud bagi Bank Umum

\section{Korupsi}

, Undang-Undang Nomor 31 Tahun 1999 Tentang Pemberantasan Tindak Pidana 